\title{
Coverage of the Self-Employed Under the Old-Age and Survivors Insurance Program
}

\author{
Harold P. Packer* and George J. Leibowitz**
}

\begin{abstract}
THE Soctal Security Act as originally enacted in 1935 excluded all self-employed persons ${ }^{1}$ from the scope of its old-age insurance provisions. ${ }^{2}$ Their exclusion at the time was predicated almost entirely on the administrative impracticability of including them on a compulsory basis under the terms of the law. ${ }^{3}$ In 1938 consideration was
\end{abstract}

*Office of the General Counsel, Federal Security Agency.

**Bureau of Old-Age and Survivors Insurance, Federal Security Agency.

The views expressed in this article are entirely those of the authors and are not to be construed as the official opinion of the Federal Security Agency.

1 The self-employed consist of two distinct groups, farm operators and the nonfarm group usually referred to as the urban self-employed. The number of farm operators varied from a low of 4,510,000 in January 1947 to a high of 5,474,000 in July. (Monthly Report of the Labor Force, Population Division, Bureau of the Census; Current Population Reports, Labor Force, P-57, Bureau of the Census.) The number of individuals who were farm operators at soine time during 1947 is estimated by the Federal Security Agency at $6,400,000$.

The number of urhan self-employed was $6,015,000$ in November 1947 (Current Population Reports, Labor Force, P-57, Bureau of the Census). The number at some time during 1946 is estimated by the Federal Security Agency at 7,200,000. Prior to World War $I I$ there was a gradual mcrease in the number of urban self-employed. Since the war, however, the number has increased quite inarkedly, possibly as much as $25 \%$, as veterans and other new entrants to self-employment have started establishments of their own. In 1940, according to Reports on Population, Burreau of the Census, about $35 \%$ of the urban self-employed were in retail establishments, $23 \%$ in service trades, $12 \%$ in construction work and $11 \%$ in the professions. The remainder were found in approximately equal proportions in inanufacturing, transportation, insurance and real estate, and wholesale establishments. (16th Census of the United States: 1940, Population, Vol. III, The Labor Force, Part 1, Table 78.)

249 STAT. (1935) 620, 622-625.

${ }^{3}$ Report of the Committee on Economic Security, H. R. Doc. No. 81, 74th Cong., 1st Sess. (1935) 25. This committee which was established by Executive Order No. 6757, June 29,1934 , to study the feasibility of adopting a social security program in this country was not unmindful of the fact that self-employed persons were also in need of old-age insurance protection. For such persons as well as for other groups not covered under a compulsory system, it recommended "the establishment of a related, but distinct, voluntary system of Government old-age annuities, ...." Ibid. at 21. A similar proposal was made by the President in his message to Congress recommending the enactment of social security legislation. Message of the President Recommending Legislation on Economic Security, H. R. Doc. No. 81, 74th Cong., 1st Sess. (1935) vi. Provision for the purchase 
again given to the question of including self-employed persons under the old-age provisions of the Social Security Act by an Advisory Council on Social Security appointed by a Senate Special Committee and the Social Security Board to study the advisability of amending the law. ${ }^{4}$ Upon analysis, however, of the problems involved in extending coverage to the self-employed, the Council advised against their inclusion. The conclusions of the Council on this issue read as follows:

Despite the reasons in its favor, extension of coverage to the selfemployed cannot be recommended at this time. The council finds that the administrative problems of obtaming reports of earnings and of collecting contributions from persons without an employer, together with the problems of financing the benefits to be paid such persons, are extremely difficult. The council believes that attempts to find a solution should be made, and urges that studies directed toward this end be continued. 5

This recommendation of the Advisory Council was accepted by Congress. In 1939 it revised the old-age provisions of the original Social Security Act extensively ${ }^{6}$ but made no provision for coverage of the self-employed.

of such annuities, up to a maximum annuity of $\$ 100$ a month, was contained in title $V$ of a hill first imtroduced in Congress to carry out the recommendations of both the Committee on Economic Security and the President. (H. R. 4142, 74th Cong.) The bill passed by the House, H. R. 7260, 74th Cong., contained no such provision and although its restoration was recommended by the Committee on Finance of the Senate (SEN. REP. No. 628, 74th Cong., 1st Sess. (1935) 9), the hill ultimately adopted by both Houses and signed by the President likewise failed to include any such provision.

4 The Advisory Council on Social Security, consisting of representatives of the puhlic, industry and lahor, was created by the Senate Special Committee on Social Security and the Social Security Board in May 1937. The announcement made at the time it was organized summarizes its purpose and the basis for its appointment. This announcement reads, in part: "At a hearing hefore the Committee on Finance of the United States Senate on February 22, 1937, it was agreed that the chairman of the Committee on Finance would appoint a special committee to cooperate with the Socinl Security Board to study the advisahility of amending titles II and VIII of the Social Security Act. The chairman of the Committee on Finance has appointed such a special committee .... It was agreed that this special committee in cooperation with the Social Security Board would appoint an Advisory Council on Social Security to assist in studying the advisability of amending titles II and VIII of the Social Security Act." Final Report of the Advisory Council on Social Security; Sex. Doc. No. 4, 76th Cong., 1st Sess. (1938) 1.

5 Ibid. at 23.

653 STAT. (1939) 1360, 1362-1378, 42 U.S.C. (1940) $\$ \$ 401-409$. The amendments accelerated the heginning date for the payment of monthly old-age henefits to ehihile individuals; and, among other changes inade in the program, provided for benefits for the wives of retired beneficiaries and for the payment of monthly benefits to the widows and minor children of deceased workers. The amendments further provided for more 
Since 1939 a number of proposals have been advanced for including self-employed persons under the old-age and survivors insurance program. Some have been made in the form of bills introduced in Congress to cover such individuals on a voluntary basis; ${ }^{7}$ other bills, similarly introduced in Congress, have proposed compulsory coverage. ${ }^{8}$ A congressional committee and the Govermment agencies charged with administering the Social Security Act, on the basis of studies made of the problem, have also recommended their inclusion. Indeed, most significant is the fact that there appears to be almost unanimous agreement on the part of all who have recently considered the question that by reason of the experience gained over more than a decade in the operation of the insurance system, it is possible to solve the administrative problems involved in extending coverage to the selfemployed. ${ }^{9}$ Under the circumstances it is highly probable that some action to effect such coverage may be taken by Congress in the reasonably near future. The purpose of this article, therefore, is to discuss some of the major problems presented in devising a plan for coverage of the self-employed and fitting it to the existing old-age and survivors insurance program.

Voluntary coverage plans generally propose old-age and survivors insurance protection for the self-employed upon election by the individual to pay the employer and employee contribution rates. ${ }^{10}$ The attractiveness of these plans seems to lie in the fact that they appear to offer an easy solution to some of the difficult problems encountered in developing a compulsory plan. Further, the proposed coverage would hardly be contested by persons concerned because it could be

liberal benefit payments to those workers who had reached or were about to reach retirement age and, in addition, opened the way for workers past age 65 to acquire benefits for themselves and their dependents under the law. Provision was also made for both administrative and judicial review of agency decisions disallowing claims for benefits.

7 78th Congress: H. R. 4383; 79th Congress: S. 1021; 80th Congress: H. R. 3457.

8 77th Congress: H. R. 7534; 78th Congress: S. 1161 and H. R. 2861; 79th Congress: S. 1050 , S. 1188, H. R. 395, H. R. 681, H. R. 3293 and H.R. 4551 ; 80th Congress: H. R. 20. Two bills in the soth Congress, H. R. 4303, and its companion bill in the Senate, S. 1679, provide for "compulsory" coverage in a limited sense. These bills call for the payment of benefits. No taxes are imposed on the self-employed, nor do the bills suggest any other methods for financing the benefits.

${ }^{9}$ Issues in Social Security (1946), A Report to the Committee on Ways and Means of the House of Representatives by the Committee's Social Security Techmical Staff, established pursuant to H. Res. 204, 79th Cong. 1st Sess., (1945) 34-37; Annual Report of the Federal Security Agency, Section Six (1946), 452; The Extension of Old-Age and Survivors Insurance to Agricultural and Domestic Service Workers and to the Self-Employed, Division of Tax Research, Treasury Department (1947), 6, 20-31.

10 See bills cited supra note 7 . 
had or ignored at their election. However, when voluntary participation in the old-age and survivors insurance program is considered from the point of view of the extent to which it would provide protection for the self-employed, and the effect such coverage would have on the program now in operation, its undesirability becomes evident.

Existimg experience with voluntary programs reveals that an elective plan would probably cover comparatively few people. ${ }^{11}$ Individuals of low incomes finding themselves pressed financially to meet current needs would not be likely to participate. As a result the program would be of little value to those most in need of the protection it would afford. The most likely participants would probably be those nearing retirement age and those who could expect to receive much more in benefits than they would pay for. Their participation, unless counterbalanced by the participation of less expensive risks, would result in a substantial net drain from the Old-Age and Survivors Insurance Trust Fund..$^{22}$ In effect, therefore, this would amount to subsidizing voluntary contributors at the expense of either those compulsorily covered or the federal treasury. A voluntary plan unrelated to the present program would not, of course, be a drain on the Trust Fund. But such a plan, too, would probably attract only a limited number of participants. Moreover, it would also be of little value to the vast majority of self-employed persons who have engaged in employment covered by the Social Security Act and have contributed under the program as "employees". ${ }^{13}$

11 Issues in Social Security, subpra note 9, at 130-138; Annual Report of the Federal Security Agency, supra note 9, at 453.

1253 STAT. (1939) 1362, 42 U.S. C. (1940) \$401.

13 More than 1.5 million or 26.8 per cent of all farm operators supplemented their farm income by wages, salaries or profits from off-farm work in 1944. 18 per cent of all farm operators reported 100 days or more work off their farms in this year, and for most of them farm work was probably an occupation of secondary importance. This was especially true of the 684,000 reporting 250 days or more work off their farms. (U.S. Census of Agriculture: 1945, Vol. II, General Report, Table 5, 236.) During a period of years the percentage of farm operators who, at some time or other, have done off-farm work is greater than the percentage reporting off-farm work during any one ycar. As a result the percentage of farm operators with some wage credits under the present old-age and survivors insurance program is greater than the 27 per cent reporting off-farm work in 1944. Farmers reporting off-farm work are more frequently located in the West than in the North or the South, according to the Census of Agriculture.

Many urban self-employed people start out as wage earners and shift to self-employment after gaiming experience and sufficient capital. In a limited survey of established self-employed individuals made by the Federal Security Agency in Philadelphia in 1944, 21 per cent of the group reported earnings from employments covered by the old-age and survivors insurance program prior to starting their own businesses. Since most of the 
The proposals for compulsory coverage of the self-employed ${ }^{14}$ would require such imdividuals to pay taxes under the Federal Insurance Contributions Act $t^{15}$ and provide them with benefits identical to those paid to persons otherwise covered under the old-age and survivors insurance program. The efficacy of these proposals depends, however, upon whether satisfactory answers can be found to a number of difficult questions. For example, what type of wage reporting systein shall the self-employed use? What part of their income from selfemployment shall they report as "wages" for tax purposes? Shall they pay only the employee rate of contributions or the combined employeremployee rate? What adjustments in benefit rates should be made to overcoine their late entry into the program; and what test shall be used to determine whether a self-employed person has, in fact, retired when he begins to draw benefits?

In considering the type of wage reporting system the self-employed shall use, there is, quite naturally, some inclination to require quarterly reports of "wages." Quarterly reporting is the system presently used by employers subject to the law ${ }^{16}$ and eligibility for benefits is based on quarters of coverage. ${ }^{1 \tau}$ Moreover, those among the selfemployed who are also employers could fulfill their obligations under this system simply by adding their names to the reports they are required to file for their employees.

There are, however, a number of serious disadvantages to this or any other system of quarterly reporting by the self-employed. Only about a third of those in the urban group of self-employed persons and less than half of the operators of farms have paid employees during the course of a year. ${ }^{18}$ Thus, even if coverage under the Social

group were 50 years of age and over, a large proportion had initiated their businesses hefore the old-age and survivors insurance program began. It is estimated by the Federal Security Agency that after the program has become well established, possibly 80 per cent of the urban self-employed will have made old-age and survivors insurance contributions as employees, before starting on their own.

14 See bills cited supra note 8.

15 INT. REv. CODE $\$ \$ 1400-1432$.

16 U. S. Treas. Reg. 106, pp. 66-67, 26 Code Fed. Regs. (Cum. Supp. 1944) pt. 402, p. 8281 .

1753 Stat. (1939) 1366, 1367, 42 U.S. C. (1940) $\$ \$ 402(\mathrm{~g})$, (h).

18 For the proportion of the urban self-employed with paid employees, see Small Business Problems, Small Business Wants Old-Age Security, Senate Committee Print No. 17, 78th Cong., 1st Sess. (1943) Table 6, p. 34. The estimates in this table, which were based on statistical data of the Bureau of Old-Age and Survivors Insurance and the Bureau of Internal Revenue, were approximately confirmed by a survey of a sample group of self-employed persons, which was made by the Federal Security Agency in Philadelphia in 1944, and by coinparisons of the number of unincorporated employers 
Security Act were also extended to include farm workers, the vast majority of the self-employed could not utilize the device of merely adding their names to reports they otherwise would be required to submit. But even more important as factors militating agamst adoption of a quarterly system of reporting by the self-employed are first, the fact that most of them determine their exact earnings only once a year for income tax purposes and secondly, the fact that farm operators, in particular, as a general rule receive the bulk of their incomes during a single season of the year. Conceivably, these disadvantages might be overcome by permitting the self-employed to report their "wages" on the basis of the assumed market value of their services. This they might be authorized to express in terms of the salaries they would have to offer to obtain substitutes capable of managing their businesses in their absence or in terms of the actual wages paid to their highest paid worker. In practice, neither of these devices could be expected to work well. When estimates of the cost of hiring substitute managers are given by self-employed persons, they tend to be in excess of actual earnings. The highest wages which such persons pay their employees, on the other hand, provide no indication of the value of their own services, except where the employees are of managerial rank and only a small minority of the self-employed have such individuals in their employ.

In contrast to a quarterly wage reporting system for the selfemployed, the Federal Security Agency and the Treasury Department have suggested a plan which goes a long way towards solving the reporting problem. ${ }^{19}$ Under this plan, self-employed persons would be required to file annual social security tax returns, very much in the way they now file income tax returns. Income data already included on the income tax return would simply be recorded on this separate form and submitted to collectors of internal revenue along with income tax returns. Moreover, if provision is also made for using the same concepts for deterinining earnings from self-employment for social security and income tax purposes, the possibility of confusion

reporting under the old-age and survivors insurance program during 1947 with the total number of nonagricultural self-employed persons shown for that year by the Monthly Reports on the Labor Force of the Census Bureau. For the proportion of farm operators with paid employees, see U. S. Census of Agriculture (1945) Vol. II, General Report, 282.

19 The Extension of Old-Age and Survivors Insurance to Agricultural and Domestic Service Workers and to the Self-Employed, supra note 9; Altmeyer, Improving Old-Age and Survivors Insurance, 9 SOCIAL SECURITX Bulletin (March 1946) 3. 
between the two and the amount of work required of taxpayers would be reduced to a minimum.

The "point of departure" of the Federal Security Agency and the Treasury Department proposal is the filing requirement of the Federal income tax law, and since all persons with gross incomes of $\$ 500$ or more from all taxable sources are now required to file income tax returns, this approach would cover a substantial proportion of the self-employed. ${ }^{20}$ In 1944 , for example, some 85 per cent of farm operators and about 90 per cent of the urban self-eniployed would have been reached by this method. Likewise, in 1939 approximately 65 per cent of farm operators had gross incomes of $\$ 500$ or more and the corresponding figure for the urban self-employed was a little under 90 per cent. ${ }^{21}$

If the number still excluded by this approach is considered excessive, it would be possible to provide that a self-employed person with a gross income of less than $\$ 500$ could file for old-age and survivors insurance purposes by reporting a small amount of income, which if continued at the same level would entitle the contributor to minimum benefits. Such a provision is probably not necessary, however, because among the excluded persons would be many part-time self-employed individuals whose earnings as employees would be covered under the program, and many retired and semi-retired persons whose farms produce primarily for home use or whose urban businesses have declined to such an extent that they yield only insignificant incomes.

Related to the problem of the method of filing is the question of determining the earnings base on which the self-employed should contribute to the program. Theoretically at least, a self-employed person

20 The amount of gross income a self-employed individual must have in order to be required to file a return for old-age and survivors insurance purposes is exclusively a policy matter. The Federal Security Agency has recommended that it be fixed at $\$ 500$. Annual Report of the Federal Security Agency, supra note 9, at 452. The Treasury uses this amount in one of the alternative proposals it makes. The Extension of Old-Age and Survivors Insurance to Agricultural and Domestic Service Workers and to the SelfEmployed, supra note 9, at 26. If Congress should accept these proposals it would be necessary to retain this figure even though the minimum gross income tax filing requirement were raised.

21 The proportions of the urban self-employed who would be covered under various plans for the extension of old-age and survivors insurance coverage are discussed in Issues ivo Social Security, supra note 9, at 36, and in The Extension of Old-Age and Survivors Insurance to Agricultural and Domestic Service Workers and to the Self-Employed, supra note 9 , at 20 . The estimates cited in the text agree approximately witl the statements in these publications. 
should contribute only on the income he receives for his personal services. This is essential if equal treatment is to be accorded to employees covered under the program and the self-employed. It is also essential if coverage of the self-employed is to be in keeping with the underlying purpose of the program, namely to provide protection against the loss of earnings by reason of old age or death.

Segregation of a self-employed individual's return on invested capital from income derived from personal services is not, however, a simple matter. At best, arbitrary distinctions must be made. But as in the case of determining what type of reporting system should be used for the self-employed, so too, in deciding what shall constitute the earnings base on which they should contribute, the present income tax system is of immeasurable assistance.

In arriving at earnings from self-employment for old-age and survivors insurance purposes through the utilization of income tax returns, such items on the return as wages or salaries, interest, dividends, capital gains, most items of rent and some types of royalties reported by self-employed persons can be disregarded. This would leave, as representing net income from self-employment, the net income from farm, business or profession which is shown in Schedule $C$ of the return, and the net income from partnerships which appears on the first line of Schedule $E .^{22}$ By modifying the instructions with regard to the income tax return, some items of rent, like those received by hotel and lodging house operators and the royalties paid to authors, composers, and inventors could be reported in Schedules $C$ or $E$.

The total net income from self-employment thus shown on the tax return would provide an adequate contribution base for the purposes of old-age and survivors insurance. To be sure, the net income from self-employment represented by these two schedules may include an element of return on invested capital, but it can reasonably be assumed in the vast majority of cases, that it consists predominantly of compensation for personal services. This is especially true in view of the maximum annual amount of earnings taxable under the program ${ }^{23}$ since earnings in excess of the maximum may be considered to be more in the nature of return on investment than those below the maximum.

Under the existing old-age and survivors insurance program, "wages" include the money value of payments in kind, such as the

20 Form 1040, Treasury Department, Internal Revenue Service; farmers use Form $1040 \mathrm{~F}$.

23 Supra note 15. 
meals furnished to the employees of hotels and restaurants. Among the self-employed, the large majority of farm operators have appreciable amounts of income-in-kind, in the form of products consumed in their own households. Since for income tax purposes farm operators have the option of including or excluding the value of home-use goods, they could be given the same option when reporting for old-age and survivors imsurance purposes. Income tax procedure could also be made applicable to the less important items of income-in-kind, represented by the differences between the wholesale and the retail value of the goods that some of the urban self-employed withdraw from their business stocks for household use.

In addition, many of the low income self-employed are not actually required to determine their net incomes accurately for income tax purposes because the deductions to which they are entitled on account of their dependents or for other reasons are so large that they are certain not to have to pay a tax. For the purposes of old-age and survivors insurance, it might be desirable to give such persons the option of using a fixed percentage of their gross business incomes as a contribution base. If such option is given, the assumed contribution base should be a percentage of gross income which excludes the cost of the goods sold by wholesale and retail merchants and some other types of self-employed persons, rather than a percentage of gross receipts. This would tend to put the merchandising and the nonmerchandising groups of the self-employed on an equal footing. Any such option, however, might be limited to self-employed persons whose gross incomes fell below a relatively small amount such as $\$ 1,000$ or $\$ 1,500$. If the gross income level at which the filing of income tax returns is required should be raised above $\$ 500$, this optional contribution base might also be found useful by many self-employed persons who had been determining their actual net incomes for income tax purposes but would be no longer required to do so.

The rate of contributions to be paid by the self-employed is exclusively a policy matter to be determined on the basis of financial and administrative considerations. Under the present program, the benefits are financed by earmarked contributions of employees and matching tax amounts paid by employers. Conceivably, therefore, if a self-employed individual is to receive wage credits for benefit purposes on earnings from self-employment, he should be required to pay both the employer and employee rates of contributions to meet the cost of the benefits. 
However, as is pointed out in the Treasury Department's analysis of the feasibility of covering the self-employed, other considerations must be taken into account. ${ }^{24}$ In some imstances a self-employed individual may perform the functions of both an employer and an employee, in which case imposition of the combined rates might seem equitable, but in other instances he more nearly resembles an employee only. In the latter situation, imposition of the combined rate would be highly inequitable. Further, from an economic standpoint it may be desirable that a self-employed person should not be placed at a competitive disadvantage with a competing incorporated employer who can deduct his social security tax payments from his income tax as a business expense or shift it elsewhere, whereas the tax payable by the self-employed under present plans is not deductible. Of course, no such disadvantage would exist if a self-employed person were also permitted to deduct a portion of his contributions as a business expense for incoine tax purposes.

Other considerations advanced for payment by the self-employed of something less than the double rate paid on behalf of the employee relate to the cost and amount of the benefits. It is urged that selfemployed individuals whose incomes remained continually at or near the taxable maximum and who would contribute over a long period of time at the combined rate would be overpaying for the protection received, in comparison with the premiums they would be required to pay for corresponding private insurance protection. Likewise it is urged that because the self-employed as a group have somewhat higher incomes than wage earners and the benefit formula is weighted in favor of lower income groups, the cost of benefits to the self-employed would be relatively low. It is, however, by no ineans certain that comparable insurance is available with private concerns or that any particular self-employed individual can qualify for it. Equally, it is by no means certain that the net incomes of the urban self-employed and farm operators combined actually tend to be greater than the incomes of all wage and salary employees so as to result in favoring either group in the payment of benefits.

In view of these considerations, two types of compromise rates have been suggested. It might be possible to require self-employed persons to contribute at one and one-half, or some other figure less than two, times the employee rate, or to require them to contribute at

24 The Extension of Old-Age and Survivors Insurance to Agricultural and Domestic Service Workers and to the Self-Em-ployed, supra note 9, at 27. 
the employee rate on the first $\$ 500$, or some higher amount, of their incomes and at the combined employer-employee rate on the balance, up to the maximum taxable. ${ }^{25}$ While these approaches have some different effects, both appear to be acceptable solutions.

If coverage is extended to the self-employed, some adjustment in the benefit amounts payable to such individuals is necessitated by reason of their late entry in the program. Under the present program, eligibility for retirement benefits is based on fully insured status which, in turn, depends on the individual having quarters of coverage credited in at least half as many calendar quarters as elapsed after 1936 or the quarter of attainment of age 21 whichever is later, and before the quarter in which he attains age $65 .^{26}$ The amount of benefits is based on his average monthly wage, which is defined in the law, as the quotient obtained by dividing total wages credited by three times the number of quarters elapsing after 1936 and before the quarter of death or entitlement to benefits, omitting any quarter prior to age 22 that was not a quarter of coverage. ${ }^{2 T}$

Should these provisions remain unchanged, the self-employed upon entry in the prograin would be at a serious disadvantage. For example, if coverage were extended to the self-employed in 1949, persons under 57 years of age who had no wage records prior to the extension of coverage would be eligible for benefits only after acquiring forty quarters of coverage. Older persons could qualify with fewer quarters depending on their ages. But once they qualified, the average monthly wage provision would result in reduced benefits because their earnings would be averaged over the entire period since 1936 rather than over the period during which the contributions had been made.

A number of proposals have been advanced to overcome these handicaps. It has been suggested that eligibility for retirement should be based on the individual having quarters of coverage in one-fourth, rather than one-half, of the number of elapsed quarters. Under another proposal the half-time test would be retained but the elapsed period would be computed from the date they are brought into the program rather than from January 1, 1937. Still another possibility would be to grant fully insured status to individuals having twenty

25 Ibid. at 28.

2653 STAT. (1939) 1376,42 U.S.C. (1940) $\$ 409(\mathrm{~g})$. An individual is also fully insured once he acquires forty quarters of coverage. But until the program is in effect at least twenty years, there will not be any cases in which individuals who fail to meet the half-time test will have forty quarters of coverage.

27 Ibid. at 1376,42 U.S. C. (1940) $\$ 409$ (f). 
quarters of coverage in the forty quarters preceding the quarter of attainment of age 65 , or any later quarter.

With respect to the average monthly wage, it has been proposed that the total wages credited be divided by three times the number of quarters of coverage rather than by three times the number of elapsed quarters. Under another suggestion two computations would be made, one based on the period since 1936, another on the period beginning with extension of coverage, and benefits would be based on the one which gives the higher result.

There are, of course, arguments which can be advanced for or against any of these proposals. By and large, however, it would seem to be unwise to make adjustments in the benefits to be paid to selfemployed persons unless, at the time they are first included under the program, coverage is also extended to a substantial number of the other groups now excluded. If coverage is extended only to one or two groups at a time, complicated adjustments in these provisions would be required when each new group is brought into the program. With a broad extension of coverage, modifications in the eligibility and average monthly wage provisions could be effected with little difficulty and without the need for later complicated adjustments.

Finally, in connection with the coverage of the self-employed special consideration may have to be given to the scope and application of the "work clause". Under the present law, no benefits are paid to an otherwise eligible individual for any month in which he renders service in covered employment for wages of $\$ 15$ or more. ${ }^{28}$

This provision raises a problem with respect to self-employment because a test of retirement for that group on a monthly basis would yield anomalous results and be extremely difficult to administer. Moreover, in view of the fact that the self-employed would report their incomes annually, it would appear to be more desirable to adopt an annual "work-clause", which would be as comparable as possible to the monthly test applied to employees. Another consideration is the fact that income from self-employment, if it is defined in terms of the income tax approach, would include some return on investments. Because of this some individuals who were actually retired in that they were not personally active in their businesses, would continue to receive substantial income from self-employment. As a result they would

28 Ibid. at 1367, 42 U. S. C. (1940) $\$ 403$ (d). The Federal Security Agency has often recommended that this provision be made more realistic by raising the permitted earnings amount to some higher figure. See Ammal Report of the Federal Security Agency, supra note 9 , at 463 . 
not seem to be in a retired status if such income is the only standard by which retirement is tested.

Among the additional criteria suggested for determining whether or not a self-employed individual is no longer actively engaged in performing service is a time test. Under this test an individual could be considered to be retired, regardless of the amount of his income from self-employment, if he did not devote a substantial amount of time to his business enterprise. Substantial time could be ineasured in terms of a fixed number of hours, and beneficiaries who engaged in self-employment would be required to report the time so spent. The difficulty with this approach is that reports of time spent would constitute an administrative burden to the Federal Security Agency and be troublesome as well for the beneficiaries involved. Moreover, it is doubtful that this additional test would result in furnishing a better guide for determining retirement than a test based entirely on income.

An alternative additional criterion might be based on a determination of the invested capital which a beneficiary, who continues to have income from self-employment, may have. A return on his capital could be imputed and the individual allowed this amount of income from self-employment without suffering any reduction in benefits. This approach would probably give somewhat more accurate results than the time test, but it would also involve administrative difficulties. It does have the advantage, however, of being less burdensome to the beneficiary.

In recognition of these difficulties, it has even been suggested that benefits not be suspended on account of self-employment and that the "work-clause" provision apply only to services rendered for wages in covered employment. Obviously, this suggestion accords much more favorable treatment to the self-employed than to wage earners and is undesirable on this count alone.

The problem, then, is to develop an annual test of retirement for the self-employed which would be understandable and simple to administer, would result in comparable treatment of the self-employed and wage earners, and would recognize to the greatest possible extent the existence of investment return in income from self-employment. A proposal which would seem to meet these specifications is one under which a beneficiary with annual income from self-employment below an amount such as $\$ 500$ or $\$ 600$ would be considered to be retired and entitled to all benefits for the year in question. This allowance would recognize the fact that net income from self-employment includes an 
element of return on capital, with the result that a person may receive such income and yet actually be retired. If his income from self-employment exceeded the exempt amount, he would be entitled to one less monthly benefit for every $\$ 40$ or $\$ 50$ of the excess, depending on the work clause amount fixed for wage earners. Thus, for example, if the exempt amount was set at $\$ 600$ and the work deduction figure at $\$ 50$ monthly, a beneficiary having income from self-employment, as defined for coverage purposes, would be considered to be fully retired if such income was $\$ 600$ or less, and partly retired (that is, entitled to one or more but less than twelve monthly benefits in a year) if his income should be between $\$ 650$ and $\$ 1,200$.

Such a provision would be relatively easy to administer. It also appears to satisfy substantially the criteria which must be considered in devising a "retirement test" for the self-employed. If, in addition, the Social Security Act were also amended to eliminate the "workclause" deduction for all beneficiaries of age 70 or older, any inequality of treatment in individual cases resulting from the application of necessarily arbitrary retirement-test provisions would be mitigated to a large extent.

The foregoing should indicate quite clearly that much progress has been made in the last decade towards solving the administrative difficulties involved in formulating a plan of coverage for the selfemployed. Of course, any system for coverage of the self-employed would not be perfect. Revisions would have to be made in the light of experience gained in its operation. But the inability as yet to devise the perfect plan should not delay coverage. The need of the selfemployed for old-age and survivors insurance protection outweighs by far considerations of perfection. 